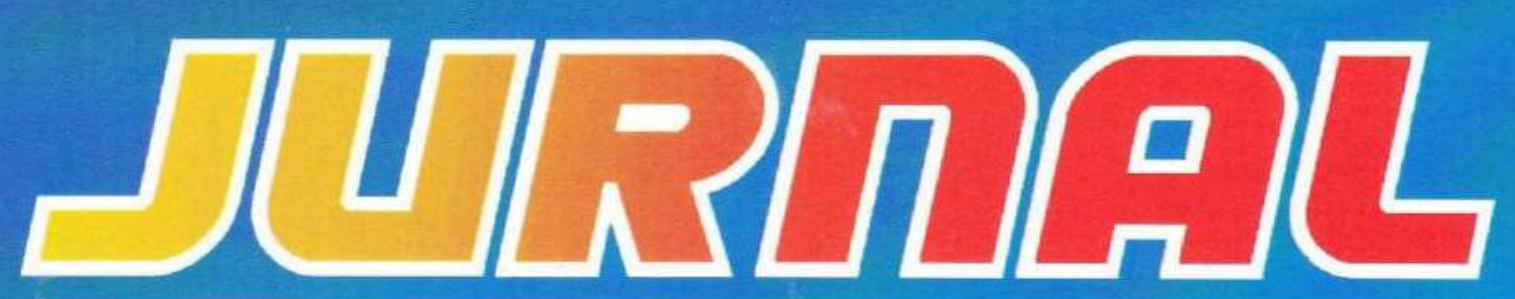

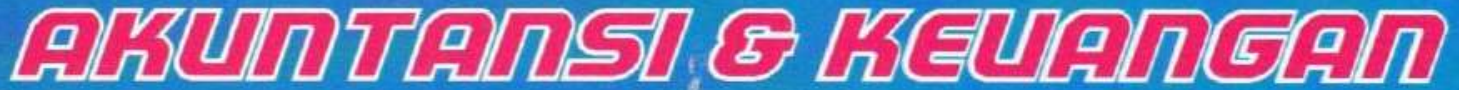

Volume 11, No. 1, Maret 2020

ISSN: $2087-2054$

Analisa Perbandingan Economic Value Added (EVA) Dan Return On Asset (ROA) Dalam Menilai Kinerja Perusahaan (Studi Kasus Pada Perusahaan Rokok Yang Terdaftar Di Bursa Efek Indonesiaperiode 2015-2018).

\section{Dewi Silvia}

Analisis Kinerja Anggaran Pendapatan Dan Belanja Daerah Pada Pemerintah Daerah Kabupaten Oku Periode 2013-2017

Hasiatul Aini, Mardiah Kenamon \& Yeni Anggraini

Analisis Kinerja Keuangan Pemerintah Daerah Oku Selatan Tahun Anggaran 2013-2017. Anis Feblin \& Yulitiawati

Pengaruh Economic Value Added (EVA) Dan Market Value Added (MVA) Terhadap Return Saham.

\section{Luke Suciyati Amna}

Analisis Rasio Keuangan Anggaran Pendapatan Dan Belanja Daerah Untuk Menilai Kinerja Keuangan Pemerintah Daerah Kabupaten Pesawaran Tahun 2010-2014.

\section{Herry Goenawan Soedarsa}

Pengaruh Kualitas Audit Dan Komite Audit Terhadap Kualitas Pelaporan Keuangan Perusahaan Yang Terdaftar Di Jakarta Islamic Index (JII).

\section{Liya Ermawati, Yulistia Devi \& Naurah Nazhifah Arramadani}




\section{JURNAL}

ARUNTANSI \& KEUANGAN

Volume 11, No. 1, Maret 2020

ISSN: $2087-2054$

Dewan Pembina

Dr. Ir. M. Yusuf S. Barusman, M.B.A

Dr. Andala Rama Putra Barusman, S.E., M.A.Ec.

Penanggung Jawab

Aminah, S.E., M.S.Ak

Pimpinan Redaksi

Dr. Haninun, S.E., M.S.Ak

Sekretaris Redaksi

Riswan, S.E., M.S.Ak

Luke Suciyati Amna, S.E., M.S.Ak

\section{Penyuting Ahli (Mitra Bestari)}

Tina Miniawati, S.E., M.B.A. (Universitas Trisakti)

Dr. Khomsiyah, S.E., M.M. (Universitas Trisakti)

Dr. Lindrianasari, S.E., M.Si.Akt., C.A. (Universitas Lampung)

Sujoko Efferin, Mcom (Hons), MA(Econ), Ph.D. (Universitas Surabaya)

\section{Penerbit}

Universitas Bandar Lampung

Fakultas Ekonomi dan Bisnis Program Studi Akuntansi

SENARAI-Jurnal Akuntansi \& Keuangan Terbit 2 kali setahun pada bulan Maret \&

September

Artikel yang dimuat berupa hasil riset Empiris dan telaah teoritis konsepsual yang kritis dalam kajian bidang akuntansi, auditing, perpajakan, dan keuangan.

\section{Alamat Redaksi}

Gedung G- Program Studi Akuntansi Fakultas Ekonomi dan Bisnis

Universitas Bandar Lampung

Kampus A Jalan Z.A Pagar Alam No. 26 Labuan Ratu Bandar Lampung 35142

Telp: (0721) 701979, Fax: (0721) 701467, Email: Prodi.akuntansi@ubl.ac.id 


\section{AKUNTANSI \& KEUANGAN}

Analisa Perbandingan Economic Value Added (EVA) Dan Return On Asset (ROA) Dalam Menilai Kinerja Perusahaan (Studi Kasus Pada Perusahaan Rokok Yang Terdaftar Di Bursa Efek Indonesiaperiode 2015-2018).

\section{Dewi Silvia}

Analisis Kinerja Anggaran Pendapatan Dan Belanja Daerah Pada Pemerintah Daerah Kabupaten Oku Periode 2013-2017

Hasiatul Aini, Mardiah Kenamon \& Yeni Anggraini

Analisis Kinerja Keuangan Pemerintah Daerah Oku Selatan Tahun Anggaran 2013-2017. Anis Feblin \& Yulitiawati

Pengaruh Economic Value Added (EVA) Dan Market Value Added (MVA) Terhadap Return Saham.

\section{Luke Suciyati Amna}

Analisis Rasio Keuangan Anggaran Pendapatan Dan Belanja Daerah Untuk Menilai Kinerja Keuangan Pemerintah Daerah Kabupaten Pesawaran Tahun 2010-2014.

\section{Herry Goenawan Soedarsa}

Pengaruh Kualitas Audit Dan Komite Audit Terhadap Kualitas Pelaporan Keuangan Perusahaan Yang Terdaftar Di Jakarta Islamic Index (JII).

Liya Ermawati, Yulistia Devi \& Naurah Nazhifah Arramadani 


\section{JURNAL}

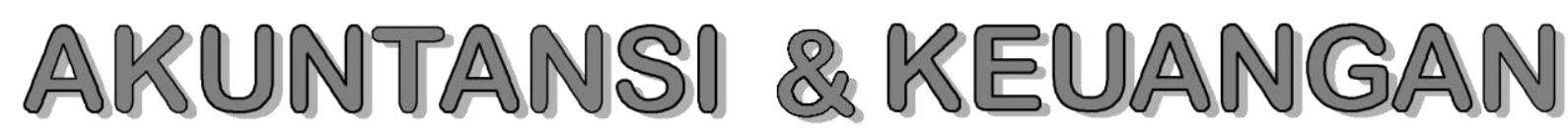

Volume 11, No. 1, Maret 2020

ISSN: $2087-2054$

Daftar Isi

Halaman

Analisa Perbandingan Economic Value Added (EVA) Dan Return On Asset (ROA) Dalam Menilai Kinerja Perusahaan (Studi Kasus Pada

Perusahaan Rokok Yang Terdaftar Di Bursa Efek Indonesiaperiode 2015-2018).

Dewi Silvia

Analisis Kinerja Anggaran Pendapatan Dan Belanja Daerah Pada

Pemerintah Daerah Kabupaten Oku Periode 2013-2017

18-34

Hasiatul Aini, Mardiah Kenamon \& Yeni Anggraini

Analisis Kinerja Keuangan Pemerintah Daerah Oku Selatan Tahun Anggaran 2013-2017.

$35-58$

Anis Feblin \& Yulitiawati

Pengaruh Economic Value Added (EVA) Dan Market Value Added (MVA)

Terhadap Return Saham.

$59-73$

Luke Suciyati Amna

Analisis Rasio Keuangan Anggaran Pendapatan Dan Belanja Daerah Untuk Menilai Kinerja Keuangan Pemerintah Daerah Kabupaten

Pesawaran Tahun 2010-2014.

Herry Goenawan Soedarsa

Pengaruh Kualitas Audit Dan Komite Audit Terhadap Kualitas Pelaporan

Keuangan Perusahaan Yang Terdaftar Di Jakarta Islamic Index (JII).

$92-111$

Liya Ermawati, Yulistia Devi \& Naurah Nazhifah Arramadani 


\section{JURNAL \\ AKUNTANSI \& KEUANGAN}

Volume 11, No. 1, Maret 2020

ISSN: 2087-2054

\section{Informasi Kebijakan dan Selingkung Berkala}

\section{Kebijakan editorial}

JURNAL Akuntansi \& Keuangan adalah sebuah berkala yang dipublikasikan oleh Universitas Bandar Lampung, yang bertujuan untuk menjadi wadah kreatifitas para akademisi, profesional, peneliti, dan mahasiswa di bidang Akuntansi dan Keuangan termasuk juga bidang Auditing, Sistem Informasi Akuntansi, Tata kelola Perusahaan, Perpajakan, Akuntansi Internasional, Akuntansi Managemen, Akuntansi Keperilakuaan, Pasar Modal dan lain sebagainya. Topik yang semakin meluas di bidang kajian riset Akuntansi diakomodir publikasinya di dalam berkala ini.

Paper yang akan dipublikasikan di dalam berkala JURNAL Akuntansi \& Keuangan harus ditulis di dalam bahasa Indonesia yang baik dan sesuai dengan EYD. Semua instrumen yang digunakan untuk memperoleh data penelitian harus dimasukkan di dalam lampiran paper penelitian, paling tidak, penulis bersedia memberikan klarifikasi atas instrumen yang digunakan saat ada permintaan dari peneliti lainnya.

\section{Sekretariat Editor Berkala}

Gedung F - Fakultas Ekonomi Universitas Bandar Lampung

Fakultas Ekonomi Program Studi Akuntansi

Kampus A Jalan Z.A. Pagar Alam No. 26 Labuhan Ratu Bandar Lampung 35142

Telp.: (0721) 701979, Fax.: (0721) 701467, Email:

\section{Petunjuk penulisan}

Artikel yang dikirim ke JURNAL Akuntansi \& Keuangan harus mengikuti petunjuk seperti berikut:

1. Naskah merupakan naskah asli yang belum pernah diterbitkan atau sedang dilakukan penilaian pada berkala lain. Naskah ditulis dalam bahasa Indonesia dengan jarak 1 spasi, sepanjang 20-30 halaman kertas A4 dengan tipe huruf Times New Roman.. Naskah dikirim atau diserahkan ke sekretariat JURNAL Akuntansi \& Keuangan rangkap satu disertai disket berikut dengan biodata penulis dan alamat lengkap (kantor dan rumah) pada lembaran yang terpisah dari halaman pertama artikel.

2. Judul naskah dapat ditulis dengan menggambarkan isi pokok tulisan, dan atau ditulis secara ringkas, jelas, dan menarik.

3. Nama Penulis disertai catatan kaki tentang profesi dan lembaga tempat penulis bekerja dalam naskah yang telah diterima untuk diterbutkan.

4. Abstrak ketik satu spasi, tidak lebih dari 250 kata dalam bahasa Inggris. Abstrak memuat tujuan penelitian, isu, permasalahan, sampel dan metode penelitian, serta hasil dan simpulan (jika memungkinan). 
5. Pendahuluan beriksikan uraian tentang latar belakang masalah, ruang lingkup penelitian, dan telaah pustaka yang terkait dengan permasalahan yang dikaji, serta rumusan hipotesis (jika ada). Uraian pendahuluan maksimum $10 \%$ total halaman.

6. Untuk penelitian kuantitatif,

a. Telaah Literatur dan Pengembangan Hipotesis memuat paling tidak satu buah teori yang menjadi dasar pemikiran penelitian. Hipotesis dikembangkan menggunakan asumsi dasar teori dan hasil penelitian sebelumnya. Telah literatur maksimum $40 \%$ total halaman.

b. Metodologi Penelitian meliputi uraian yang rinci tentang bahan yang digunakan, metoda yang dipilih, teknik, dan cakupan penelitian. Uraian bahan dan metoda maksimum $20 \%$ total halaman.

7. Untuk penelitian kualitatif menyesuaikan dengan metodologi kualitatif.

8. Hasil dan Pembahasan merupakan uraian obyektif dari-hasil penelitian dan pembahasan dilakukan untuk memperkaya makna hasil penelitian. Uraian hasil dan pembahasan minimum $25 \%$ total halaman.

9. Simpulan yang merupakan rumusan dari hasil-hasil penelitian. Harus ada sajian dalam satu kalimat inti yang menjadi simpulan utama. Simpulan maksimum $10 \%$ dari keseluruhan lembar artikel.

10. Referensi (Daftar Pustaka) ditulis berurutan berdasarkan alphabetical, disusun menggunakan suku kata terakhir dari nama penulisnya, atau institusi jika dikeluarkan oleh organisasi.

a. Buku: nama penulis, tahun penerbitan, judul lengkap buku, penyunting (jika ada), nama penerbit, dan kota penerbitan.

b. Artikel dalam buku: nama penulis, tahun penerbitan, judul artikel/tulisan, judul buku, nama penyunting, kota penerbitan, nama penerbit, dan halaman.

c. Terbitan berkala: nama penulis, tahun penerbitan, judul tulisan, judul terbitan (bila disingkat, sebaiknya menggunakan singkatan yang baku), volume, nomor, dan halaman.

d. Artikel dalam internet: nama penulis, judul, dan situsnya.

e. Tabel diberi nomor dan judul dilengkapi dengan sumber data yang ditulis dibawah badan tabel, diikuti tempat dan waktu pengambilan data.

f. Ilustrasi dapat berupa gambar, grafik, diagram, peta, dan foto diberi nomor dan judul.

11. Setiap referensi yang digunakan di dalam naskah artikel menggunakan petunjuk yang dirujuk pada The Indonesian Journal of Accounting Research, sebagai berikut:

A. Kutipan dalam tubuh naskah paper harus disesuaikan dengan contoh berikut:

I. Satu sumber kutipan dengan satu penulis (Brownell, 1981).

II. Satu sumber kutipan dengan dua penulis (Frucot dan Shearon, 1991).

III. Satu sumber kutipan dengan lebih dari satu penulis (Hotstede et al., 1990).

IV. Dua sumber kutipan dengan penulis yang berbeda (Dunk, 1990; Mia, 1988).

V. Dua sumber kutipan dengan satu penulis (Brownell, 1981, 1983).

VI. Dua sumber kutipan dengan satu penulis diterbitkan pada tahun yang sama (Brownell, 1982a, 1982b).

VII. Sumber kutipan dari lembaga harus dinyatakan dengan menggunakan akronim institusi (FASB, 1994)

B. Setiap artikel harus menulis referensi menggunakan panduan berikut:

I. Referensi harus tercantum dalam urutan abjad dari nama belakang penulis atau nama lembaga. 
II. Referensi harus dinyatakan dengan urutan sebagai berikut: penulis (s) nama, tahun publikasi, judul kertas atau buku teks, nama jurnal atau penerbit dan nomor halaman. Contoh:

a) Amerika Akuntansi Association, Komite Konsep dan Standar Laporan Keuangan Eksternal. 1977. Pernyataan tentang Teori Akuntansi dan Teori Penerimaan. Sarasota, FL: AAA.

b) Demski, J. S., dan D. E. M. Sappington. 1989. Struktur hirarkis dan akuntansi pertanggungjawaban, Jurnal Akuntansi Penelitian 27 (Spring): 40-58.

c) Dye, R. B., dan R. Magee. 1989. Biaya Kontijensi untuk perusahaan audit. Kertas kerja, Northwestern University, Evansto, IL.

d) Indriantoro, N. 1993. Pengaruh Penganggaran Partisipatif Terhadap Prestasi Kerja dan Kepuasan Kerja dengan Locus of Control dan Dimensi Budaya sebagai Moderating Variabel. Ph.D. Disertasi. University of Kentucky, Lexington.

e) Naim, A. 1997. Analisis Penggunaan Akuntansi Biaya Produk Dalam Keputusan Harga oligopolistik. Jurnal Ekonomi Dan Bisnis Indonesia 12 (3): 43-50.

f) Porcano, T. M. 1984a. Keadilan distributif dan Kebijakan Pajak. Akuntansi Ulasan 59 (4): 619-636.

g) --------. 1984b. Pengaruh Persepsi Kebijakan Pajak Niat Investasi Perusahaan. The Journal of American Association Perpajakan 6 (Fall): 719.

h) Pyndyk, R. S. dan D. L. Rubinfield. 1987. Model ekonometrik \& Forecasts Ekonomi, 3rd ed. NY: McGraw-Hill Publishing, Inc.

12. Author(s) harus melampirkan CV, alamat email, alamat korespondensi dan pernyataan yang menyatakan pasal tersebut tidak sedang disampaikan kepada atau diterbitkan oleh jurnal lain dalam email tersebut dan /atau pos. 


\title{
ANALISIS KINERJA ANGGARAN PENDAPATAN DAN BELANJA DAERAH PADA PEMERINTAH DAERAH KABUPATEN OKU PERIODE 2013-2017
}

\author{
Hasiatul Aini* \\ Mardiah Kenamon* \\ Yeni Anggraini***
}

(*Dosen Tetap Fakultas Ekonomi Dan Bisnis Universitas Baturaja)

(*Dosen Tetap Fakultas Ekonomi Dan Bisnis Universitas Baturaja)

(**Mahasiswa Fakultas Ekonomi Dan Bisnis Universitas Baturaja)

\begin{abstract}
Data used is secondary data. The analysis models used in this study are the ratio of the degree of decentralization, the ratio of regional financial dependency, the ratio of effectiveness and efficiency of Own-Source Revenue, ratio of expenditure efficiency, ratio of regional expenditure to GRDP. The results find that the ratio of the degree of decentralization is Very Less, the ratio of regional financial dependence is Very High, Own-Source Revenue is Effective, ratio of Own-Source Revenue is efficient and the ratio of expenditure efficiency is quite Efficient. The analysis of Own-Source Revenue in the District Government of Ogan Komering Ulu in the period of 2013-2017 is effective, while regional expenditure is efficient.
\end{abstract}

Keywords: Performance, Revenue, Local Expenditures

\section{PENDAHULUAN}

Pemerintah Daerah terdiri atas pemerintah daerah provinsi dan pemerintah kabupaten/pemerintah kota. Tujuannya adalah sama yaitu memajukan kesejahteraan umum dan masyarakat. Untuk mencapai tujuan sebagaimana yang dikemukakan pada tujuan bernegara pada UUD 1945 bukanlah sebuah pekerjaan yang mudah. Ada banyak masalah atau persoalan yang dihadapi untuk mencapainya, pemerintah yang ditugasi untuk mewujudkan tujuan tersebut. Untuk itu semangat desentralisasi, demokrasi, transparansi dan akuntabilitas menjadi sangat dominan dalam mewarnai proses 
penyelenggaraan pemerintahan pada umumnya dan proses pengelolaan keuangan daerah pada khususnya.

Kabupaten OKU sebagai salah satu Kabupaten di Wilayah Propinsi Sumatera Selatan, ditengah-tengah kegiatan pembangunan fisik atau pembangunan penyediaan fasilitas-fasilitas umum bagi masyarakat juga membutuhkan dana yang cukup besar. Untuk itu, penerimaan dari Pendapatan Asli Daerah (PAD) Kabupaten OKU diharapkan mampu untuk membiayai proses pembangunan tersebut.

Mencermati perkembangan APBD 2013-2017 yang dikonsolidasikan, maka melalui analisis APBD dapat diketahui seberapa besar kemampuan suatu daerah dapat menggerakan roda perekonomian daerah dan tinggi rendahnya pelayanan publik yang menggambarkan peran pemerintah daerah sebagai aktor dan fasilitator pembangunan.

Diketahui bahwa jumlah pembiayaan (tahun 2013 sebesar Rp. 115.195.400623,24 kemudian pada tahun 2014 sebesar Rp. 69.732.547.079,91, pada tahun 2015 sebesar Rp. 171.481.933.876,48, pada tahun 2014 sebesar Rp. 52.165.780.746,17 dan tahun 2017 sebesar Rp. 34.437.869.653,00.

Permasalahan lain adalah adanya pertumbuhan pendapatan daerah lebih lambat dibandingkan intensitas pertumbuhan kebutuhan anggaran untuk pelayana publik, sehingga dengan keterbatasan kapabilitas pendapatan, menyulitkan perencanaan alokasi belanja untuk pelayanan publik. Akibatnya seirng terjadi belanja daerah untuk layanan publik menjadi kurang fokus terhadap pencapaian target-target pembangunan yang diharapkan.

\section{TINJAUAN PUSTAKA}

\section{Pendapatan Daerah}

Menurut Halim (2014:69) daerah merupakan " penerimaan daerah yang berasal dari lain-lain milik pemerintah daerah". Menurut Halim (2014:69), jenis penndapatan ini meliputi objek pendapatan sebagai berikut :

1) Hasil penjualan aset daerah yang tidak dipisahkan

2) Penerimaan jasa giro

3) Penerimaan bunga deposit

4) Denda keterlambatan pelaksanaan pekerjaan 
5) Penerimaan ganti rugi atas kerugian/kehilangan kekayaan daerah.

Pendapatan Asli Daerah (PAD) merupakan salah satu komponen sumber penerimaan daerah selain penerimaan dan transfer, dan lain-lain pendapatan yang sah. Keseluruhannya merupakan sumber pendanaan penyelenggaran pemerintahan di daerah.

\section{Dana Alokasi Umum}

Dana alokasi umum adalah trasfer dana yang bersifat bock grant, sehingga pemerintah daerah mempunyai keleluasaan di dalam pengguaan DAU sesuai dengan kebutuhan dan aspirasi masing-masing daerah.

\section{Dana Alokasi Khusus}

Dana alokasi khusus (DAK) adalah dana yang bersumber dari APBN yang dialokasikan kepada daerah tertentu dengan tujuan untuk membantu mendanai kegiatan khusus yang merupakan urusan daerah dan sesuai dengan prioritas nasional. DAK dialokasikan untuk membantu daerah mendanai kebutuhan fisik sarana dan prasarana dasar yang merupakan prioritas nasional di bidang pendidikan, kesehatan (pelayanan dasar dan pelayanan rujukan), jalan, irigasi, air minum, sanitasi, prasarana pemerintahan, kelautan dan perikanan, pertanian, lingkungan hidup, keluarga berencana, kehutanan, sarana dan prasarana perdesaan, serta perdagangan (Halim, 2014 : 133).

\section{Belanja daerah}

Belanja daerah adalah semua kewajiban daerah yang diakui sebagai pengurang nilai kekayaan bersih dalam periode tahun anggaran yang bersangkutan. (UU No. 33/2004 pasal 1). Belanja daerah dipergunakan dalam rangka mendanai pelaksanaan urusan pemerintahan yang menjadi kewenangan propinsi/kabupaten/kota yang terdiri atas urusan wajib, urusan pilihan, dan urusan yang penanganannya dalam bagian atau bidang tertentu yang dapat dilaksanakan bersama pemerintah pusat dan pemerintah daerah atau antar pemerintah daerah yang ditetapkan dengan ketentuan perundangundangan.

\section{Rasio Keuangan APBD}

Menurut Mardiasmo (2014:123) Analisis Rasio Keuangan Anggaran Pendapatan dan Belanja Daerah dapat dilakukan dalam dua (2) bagian yaitu: 


\section{Analisis Pendapatan}

Analisis terhadap varian pendapatan daerah secara umum terlihat dari realisasi pendapatan dan anggarannya. Apabila realisasi melampaui anggaran (target) maka kinerja dapat dinilai dengan baik. Penilaian kinerja pendapatan pada dasarnya tidak cukup hanya melihat apakah realisasi pemdapatan daerah telah melampaui target anggaran, namun perlu dilihat lebih lanjut kompenen pendapatan apa yang paling berpengaruh. Berdasarkan laporan realisasi anggaran, kita dapat melakukan analisis pendapatan daerah dengan cara:

\section{a. Analisis Varians (Selisih) Anggaran Pendapatan}

Analisis Varians anggaran pendapatan dilakukan dengan cara menghitung selisih antara realisasi pendapatan dengan yang di anggarkan. Biasanya selisih anggaran sudah di informasikan dalam laporan realisasi anggaran yang sudah disajikan oleh pemerintah daerah. Informasi selisih anggaran tersebut sangatmembantu pengguna laporan dalam memahami dan menganalisis kinerja pendapatan.

\section{b. Rasio Derajat Desentralisasi fiskal}

Rasio ini menunjukan kewenangan dan tanggung jawab yang diberikan pemerintah pusat kepada pemerintah daerah untuk menggali dan mengelola pendapatan. Semakin tinggi kontribusi PAD, maka semakin tinggi kemampuan pemerintah daerah dalam penyelenggaraa desentralisasi.

$$
\begin{aligned}
& \overline{1 .} \\
& \text { Derajat desentralisasi }=\frac{\text { Pendapatan asli Daerah (PAD) }}{\text { Total Pendapatan Daerah }} \times 100 \%
\end{aligned}
$$

c. Rasio Ketergantungan Keuangan Daerah

Rasio ketergantungan keuangan daerah dihitung dengan cara membandingkan jumlah pendapatan transfer yang diterima oleh penerimaan daerah dengan total penerimaan daerah. Semakin tinggi rasio ini maka semakin besar tingkat ketergantungan pemerintah daerah terhadap pemerintah pusat dan/atau pemerintah propinsi.

Rasio Ketergantungan Keuangan Daerah $\frac{\text { Pendapatan Transfer }}{\text { Total Pendapatan Daerah }} \times 100 \%$

d. Rasio Efektivitas dan Efisiensi Pendapatan asli Daerah 
Rasio efektifitas PAD dihitung dengan cara membandingkan realisasi penerimaan PAD dengan target penerimaan PAD (dianggarkan).

Rasio Efektivitas PAD $\frac{\text { Realisasi Penerimaan PAD }}{\text { Target Penerimaan PAD }} \times 100 \%$

II

$\overline{1]}$

Rasio Efisiensi PAD $\frac{\text { Biaya Pemerolehan PAD }}{\text { Target Penerimaan PAD }} \times 100 \%$

\section{Analisis Belanja}

Analisis belanja merupakan analisis terhadap perbedaan atau selisih antara realisasi dengan anggaran. Berdasarkan laporan realisasi anggaran yang disajikan, pembaca laporan dapat mengetahui secara langsung besarnya varians anggaran belanja dengan realisasinya yang biasa dinyatakan dalam bentuk nilai nominalnya atau persentasenya. Kinerja pemerintah daerah dinilai baik apabila jika realisasi belanja lebih rendah dari yang dianggarkan, jika realisasi belanja lebih besar dari jumlah yang dianggarkan maka hal itu mengindikasikan adanya kinerja anggaran yang kurang baik.

Rasio Efisiensi Belanja $\frac{\text { Realisasi Belanja }}{\text { Anggaran Belanja }} \times 100 \%$

\section{Penelitian Sebelumnya}

Faqihudin (2011) melakukan penelitian tentang "Analisis Kinerja Anggaran Pendapatan dan Belanja Daerah Kota Tegal sebagai Indikator Layanan Publik". Alat analisis menggunakan Analisis Varians Belanja, Analisis Pertumbuhan Belanja, Analisis Pembiayaan, dan Analisis Keserasian Belanja. Hasil penelitian didapatkan bahwa dari kelima analisis yang digunakan dalam mengukur kinerja APBD Kota Tegal yaitu analisis varians belanja, analisis pertumbuhan belanja, analisis efisiensi belanja, analisis pembiayaan kecuali analisis keserasian belanja menunjukkan hasil yang cukup baik sehingga dari sisi analisis ini kinerja APBD Kota Tegal menunjukkan hasil yang positif.

Gozaliem (2013) melakukan penelitian tentang "Analisis Pendapatan Dan Belanja Pada Pemerintah Kota Bitung tahun anggaran 2010-2012. Alat analisis menggunakan rasio derajat desentralisasi ,rasio ketergantungan keuangan daerah, rasio efektifitas pada, analisis varians belanja, rasio efisiensi belanja. Hasil penelitiannya menunjukkan bahwa pendapatan belum 
dapat terlaksana dengan baik karena realisasi meningkat setiap tahun melebihi yang dianggarkan.

Sudarwanto (2013) melakukan penelitian tentang "Analisis Anggaran Pendapatan Belanja Daerah Pada Propinsi DKI Jakarta Tahun Anggaran 2009-2012" Alat analisis yang dugunakan adalah rasio pajak, rasio pajak perkapita. Dari hasil penelitian menunjukkan bahwa anggaran Pendapatan Belanja Daerah dengan realisasinya pada Propinsi DKI Jakarta tahun anggaran 2009-2011,Kinerja pendapatan pemerintah DKI Jakarta dilihat dari analisis Varians, secara umum dapat dikatakan sudah baik.

\section{METODE PENELITIAN}

\section{Ruang Lingkup Penelitian}

Penelitian ini membahas kinerja Pendapatan dan Belanja Daerah Pada Daerah Kabupaten OKU Periode 2013-2017. Penelitian ini membatasi tentang rasio derajat desentralisasi, rasio ketergantungan keuangan daerah, rasio efektivitas dan efisiensi PAD, rasio efisiensi belanja, rasio belanja daerah pada tahun 2013-2017.

\section{Data dan Sumber Data}

Penlitian ini berbentuk survey atas data sekunder, data sekunder merupakan data yang diperoleh secara tidak langsung melalui media perantara, data sekunder tersebut diperoleh dari BPKAD Kabupaten OKU. Data yang digunakan berupa laporan APBD Kabupaten Ogan Komering Ulu tahun 2013-2017.

\section{Teknik Analisis}

\section{Analisis Kualitatif}

Data yang berupa angka atau data yang berbentuk penyelesaian yang tidak dapat dinyatakan dalam bentuk angkatan analisa angka dengan uraian kalimat penjelas guna menyampaikan informasi yang digunakan oleh peneliti yang berbentuk penjelasan.

\section{Alat Analisis}

Model analisis yang digunakan dalam penelitian ini menggunakan rasio derajat desentralisasi, rasio ketergantungan keuangan daerah, rasio efektivitas dan efisiensi PAD, rasio efisiensi belanja, rasio belanja daerah 
terhadap PDRB. Adapun model yang digunakan dalam penelitian dapat diiformulasikan sebagai berikut

1. Rasio Derajat Desentralisasi

Derajat desentralisasi $\frac{\text { Pendapatan asli Daerah (PAD) }}{\text { Total Pendapatan Daerah }} \times 100 \%$

Kriteria Derajat Desentralisasi

\begin{tabular}{|c|c|}
\hline $\begin{array}{c}\text { Persentase Total } \\
\text { PendapatanAsli Daerah } \\
\text { terhadap TotalPendapatan } \\
\text { Daerah }\end{array}$ & $\begin{array}{c}\text { Tingkat Desentralisasi } \\
\text { Fiskal }\end{array}$ \\
\hline $0,00-10,00$ & Sangat Kurang \\
\hline $10,01-20,00$ & Kurang \\
\hline $20,01-30,00$ & Sedang \\
\hline $30,01-40,00$ & Cukup \\
\hline $40,01-50,00$ & Baik \\
\hline$>50,00$ & Sangat baik \\
\hline
\end{tabular}

Sumber : ( Bisma dan Susanto, 2010 : 77 )

2. Rasio Ketergantungan Keuangan Daerah

Rasio Ketergantungan Keuangan Daerah $\frac{\text { pendapatan Transfer }}{\text { Total Pendapatan Daerah }} \times 100 \%$

Kriteria Penilaian Ketergantungan Keuangan Daerah

\begin{tabular}{|c|c|}
\hline $\begin{array}{c}\text { Prosentase PAD } \\
\text { Terhadap Total } \\
\text { Penerimaan Non Subsidi }\end{array}$ & $\begin{array}{c}\text { Ketergantungan } \\
\text { Keuangan Daerah }\end{array}$ \\
\hline $0,00 \%-10,00 \%$ & Sangat Rendah \\
\hline $10,01 \%-20,00 \%$ & Rendah \\
\hline $20,01 \%-30,00 \%$ & Sedang \\
\hline $30,01 \%-40,00 \%$ & Cukup \\
\hline
\end{tabular}


Analisis Kinerja Anggaran Pendapatan Dan Belanja

\begin{tabular}{|c|c|}
\hline $40,01 \%-50,00 \%$ & Tinggi \\
\hline$>50,00 \%$ & Sangat Tinggi \\
\hline
\end{tabular}

Sumber : ( Bisma dan Susanto, 2010 : 77 )

3. Rasio Efektivitas dan Efisiensi Pendapatan asli Daerah

a. Rasio Efektivitas Pendapatan Asli Daerah

Rasio Efektivitas PAD $\frac{\text { Realisasi Penerimaan PAD }}{\text { Target Penerimaan PAD }} \times 100 \%$

Kriteria Penilaian Efektivitas

\begin{tabular}{|c|c|}
\hline $\begin{array}{c}\text { Prosentase PAD } \\
\text { Terhadap Total } \\
\text { Penerimaan Non Subsidi }\end{array}$ & Efektivitas \\
\hline Di atas $100 \%$ & Sangat efektif \\
\hline $90 \%-100 \%$ & Efektif \\
\hline $80 \%-90 \%$ & Cukup Efektif \\
\hline $60 \%-80 \%$ & Kurang Efektif \\
\hline Kurang dari $60 \%$ & Tidak Efektif \\
\hline
\end{tabular}

Sumber : ( Bisma dan Susanto, 2010 : 78 )

b. Rasio Efisiensi Pendapatan Asli Daerah

Rasio Efisiensi PAD $\frac{\text { Biaya Pemerolehan PAD }}{\text { Realisasi Penerimaan PAD }} \times 100 \%$

Kriteria Penilaian Efisiensi PAD

\begin{tabular}{|c|c|}
\hline $\begin{array}{c}\text { Presentase Kinerja } \\
\text { Keuangan }\end{array}$ & Kriteria \\
\hline $100 \%$ ke atas & Tidak Efisien \\
\hline $90 \%-100 \%$ & Kurang Efisien \\
\hline $80 \%-90 \%$ & Cukup Efisien \\
\hline
\end{tabular}




\begin{tabular}{|c|c|}
\hline $60 \%-80 \%$ & Efisien \\
\hline Di bawah 60\% & Sangat Efisien \\
\hline
\end{tabular}

Sumber : ( Bisma dan Susanto, 2010 : 79 )

4. Rasio Efisiensi Belanja

Rasio Efisiensi Belanaja $\frac{\text { Realisasi Belanja }}{\text { Anggaran Belanja }} \times 100 \%$

\begin{tabular}{|c|c|}
\hline Nilai & Kriteria \\
\hline $100 \%$ ke atas & Tidak Efisien \\
\hline $90 \%-100 \%$ & Kurang Efisien \\
\hline $80 \%-90 \%$ & Cukup Efisien \\
\hline $60 \%-80 \%$ & Efisien \\
\hline Di bawah $60 \%$ & Sangat Efisien \\
\hline
\end{tabular}

Sumber : ( Bisma dan Susanto, 2010 : 79 )

\section{HASIL ANALISIS DAN PEMBAHASAN}

\section{Hasil Analisis}

Analisis yang digunakan dalam penelitian ini menggunakan rasio derajat desentralisasi, rasio ketergantungan keuangan daerah, rasio efektivitas PAD dan rasio efisiensi PAD, dan rasio efisiensi belanja PAD. Adapun analisis yang dilakukan terhadap kinerja anggaran pendapatan dan belanja daerah pada Pemerintah Daerah Kabupaten OKU periode 2013-2017 sebagai berikut:

\section{Rasio Derajat Desentralisasi}

Rasio ini menunjukan kewenangan dan tanggung jawab yang diberikan pemerintah pusat kepada pemerintah daerah untuk menggali dan mengelola pendapatan. Semakin tinggi kontribusi PAD, maka semakin tinggi kemampuan pemerintah daerah dalam penyelenggaraan desentralisasi. 
rasio derajat desentralisasi pada Pemerintah Kabupaten Ogan Komering Ulu pada tahun 2013 sebesar 4,56 (Sangat Kurang), kemudian pada tahun 2014 rasio derajat desentralisasi meningkat menjadi 7,32 (Sangat Kurang), selanjutnya pada tahun 2015 rasio derajat desentralisasi kembali mengalami peningkatan menjadi 9,54 (Sangat Kurang), di tahun 2016 rasio desentralisasi menunjukkan angka 7,34 (Sangat Kurang). Derajat desentralisasi Kabupaten OKU pada tahun 2013-2016 dalam kategori kurang, kemudian pada tahun 2017 rasio derajat desentralisasi mengalami peningkatan yang cukup signifikan yaitu sebesar 12,32 (Kurang). Adapun rata-rata rasio derajat desentralisasi pada Pemerintah Kabupaten Ogan Komering Ulu periode tahun 2013-2017 didapatkan nilai 8,22 yang berarti bahwa derajat desentralisasi pada Pemerintah Kabupaten Ogan Komering Ulu dikategorikan Sangat Kurang. Dilihat dari Pendapatan Asli Daerah relatif lebih kecil. Kontribusi tersebut dapat dilihat selama 5 (lima) tahun terakhir dari persentase rata-rata yang hanya sebesar 8,22\%. Untuk itu, PAD merupakan upaya yang perlu dilakukan oleh Kabupaten Ogan Komering Ulu, belum optimalnya pemungutan retribusi daerah dan pajak daerah menunjukkan bahwa jasa yang dapat dijual masih kurang. Hal ini berarti dalam mengelola daerah, selain berorientasi publik service juga bersifat profit making. Maka dari itu Pemerintah Kabupaten Ogan Komering Ulu harus mengoptimalkan potensi-potensi PAD diantaranya adalah melalui peningkatan pemungutan pajak dan retribusi daerah yang sudah tergali dan sudah terpungut oleh daerah Kabupaten Ogan Komering Ulu.

\section{Rasio Ketergantungan Keuangan Daerah}

Rasio ketergantungan keuangan daerah dihitung dengan cara membandingkan jumlah pendapatan transfer yang diterima oleh penerimaan daerah dengan total penerimaan daerah. Semakin tinggi rasio ini maka semakin besar tingkat ketergantungan pemerintah daerah terhadap pemerintah pusat dan/atau pemerintah provinsi.

rasio ketergantungan keuangan daerah pada Pemerintah Kabupaten Ogan Komering Ulu pada tahun 2013 sebesar 79,81 (Sangat Tinggi), kemudian pada tahun 2014 rasio ketergantungan keuangan daerah meningkat menjadi 84,32 (Sangat Tinggi), selanjutnya pada tahun 2015 rasio ketergantungan keuangan daerah kembali mengalami peningkatan menjadi 86,65 (Sangat Tinggi), di tahun 2016 rasio ketergantungan keuangan daerah menunjukkan angka 89,08 (Sangat Tinggi) dan pada tahun 2017 rasio ketergantungan keuangan daerah mengalami penurunan yang cukup signifikan yaitu sebesar 73,90 (Sangat Tinggi). Adapun rata-rata rasio ketergantungan keuangan daerah pada Pemerintah Kabupaten Ogan Komering Ulu periode tahun 2013-2017 didapatkan nilai 82,75 yang berarti bahwa rasio ketergantungan 
keuangan daerah pada Pemerintah Kabupaten Ogan Komering Ulu dikategorikan Sangat Tinggi. Ketergantungan daerah terhadap pusat masih sangat tinggi, hal ini disebabkan karena pemerintah belum optimal meningkatan PAD serta masih tergantung pada pemerintah pusat serta kurangnya peningkatan fungsi perusahaan daerah.

\section{Rasio Efektivitas Pendapatan Asli Daerah}

Rasio efektifitas PAD dihitung dengan cara membandingkan realisasi penerimaan PAD dengan target penerimaan PAD (dianggarkan).

rasio efektivitas Pendapatan Asli Daerah pada Pemerintah Kabupaten Ogan Komering Ulu pada tahun 2013 sebesar 95,87 (Efektif), kemudian pada tahun 2014 rasio efektivitas Pendapatan Asli Daerah mengalami penurunan menjadi 98,01 (Efektif), selanjutnya pada tahun 2015 rasio efektivitas Pendapatan Asli Daerah kembali mengalami penurunan menjadi 92,45 (efektif), di tahun 2016 rasio efektivitas Pendapatan Asli Daerah mengalami peningkatan dari sebelumnya yaitu 106,,71 (Sangat Efektif) dan pada tahun 2017 rasio efektivitas Pendapatan Asli Daerah mengalami peningkatan yang cukup signifikan yaitu sebesar 114,46 (Sangat Efektif). Adapun rata-rata rasio efektivitas Pendapatan Asli Daerah pada Pemerintah Kabupaten Ogan Komering Ulu periode tahun 2013-2017 didapatkan nilai 101,50 yang berarti bahwa efektivitas Pendapatan Asli Daerah pada Pemerintah Kabupaten Ogan Komering Ulu dikategorikan Sangat Efektif. Hal ini disebabkan dalam pengelolaan pendapatan daerah, pemerintah menargetkan pendapatan tidak terlalu besar dengan perkiraan /terealisasi sehingga pemerintah Kabupaten Ogan Komering Ulu dapat mencapai target yang diinginkan. Ini menunjukkan bahwa pemerintah Kabupaten Ogan Komering Ulu telah menganggarkan Pendapatan Asli Daerah dengan cukup baik.

\section{Rasio Efisiensi Pendapatan Asli Daerah}

Rasio efisiensi PAD dihitung dengan cara membandingkan biaya yang digunakan dalam pemungutan PAD (Biaya Pemerolehan PAD) dengan realisasi penerimaan PAD.

rasio efisiensi Pendapatan Asli Daerah pada Pemerintah Kabupaten Ogan Komering Ulu pada tahun 2013 sebesar 69,38 (Efisien), kemudian pada tahun 2014 rasio efisiensi Pendapatan Asli Daerah menurun menjadi 66,80 (Efisien), selanjutnya pada tahun 2015 rasio Pendapatan Asli Daerah kembali mengalami penurupan menjadi 54,68 (Sangat Efisien), di tahun 2016 rasio efisiensi Pendapatan Asli Daerah mengalami peningkatan yaitu 65,63 (Efisien) dan pada tahun 2017 rasio efisiensi Pendapatan Asli Daerah mengalami penurunan yaitu sebesar 50,87 (Sangat Efisien). Adapun ratarata rasio efisiensi pada Pemerintah Kabupaten Ogan Komering Ulu periode 
tahun 2013-2017 didapatkan nilai 61,47 yang berarti bahwa efisiensi Pendapatan Asli Daerah pada Pemerintah Kabupaten Ogan Komering Ulu dikategorikan Efisien. Hal ini disebabkan dalam pengelolaan pendapatan daerah, pemerintah menargetkan pendapatan tidak terlalu besar dengan perkiraan /terealisasi sehingga pemerintah Kabupaten Ogan Komering Ulu dapat mencapai target yang diinginkan. Ini menunjukkan bahwa pemerintah Kabupaten Ogan Komering Ulu telah menganggarkan Pendapatan Asli Daerah dengan cukup baik.

\section{Rasio Efisiensi Belanja}

Analisis belanja merupakan analisis terhadap perbedaan atau selisih antara realisasi dengan anggaran. Berdasarkan laporan realisasi anggaran yang disajikan, pembaca laporan dapat mengetahui secara langsung besarnya varians anggaran belanja dengan realisasinya yang biasa dinyatakan dalam bentuk nilai nominalnya atau persentasenya. Kinerja pemerintah daerah dinilai baik apabila jika realisasi belanja lebih rendah dari yang dianggarkan, jika realisasi belanja lebih besar dari jumlah yang dianggarkan maka hal itu mengindikasikan adanya kinerja anggaran yang kurang baik.

Rasio efisiensi belanja merupakan perbandingan antara realisasi belanja dengan anggaran belanja. Rasio efisiensi belanja ini di gunakan untuk mengukur tingkat penghematan anggaran yang dilakukan pemerintah. rasio efisiensi belanja pada Pemerintah Kabupaten Ogan Komering Ulu pada tahun 2013 sebesar 88,29 (Cukup Efisien), kemudian pada tahun 2014 rasio efisiensi belanja menurun menjadi 87,90 (Cukup Efisien), selanjutnya pada tahun 2015 rasio efisiensi belanja kembali mengalami peningkatan menjadi 88,95 (Cukup Efisien), di tahun 2016 rasio efisiensi belanja mengalami penurunan namun tidak terlalu signifikan yaitu 88,24 (Cukup Efisien) dan pada tahun 2016 mengalami peningkatan yaitu sebesar 91,42 (Kurang Efisien). Rasio efeisien belanja Kabupaten OKU pada tahun 2013-2017 berada di kategori cukup efisien, hal ini disebabkan karena biaya yang dikeluarkan oleh Pemerintah Kabupaten Ogan Komering Ulu dalam melakukan pemungutan pajak, retribusi dan kekayaan daerah sudah tepat dan sesuai. Kemudian pada tahun 2017 rasio efisiensi belanja mengalami peningkatan yang cukup signifikan yaitu sebesar 91,42 (Kurang Efisien) hal ini disebabkan karena pemerintah Kabupaten OKU mampun melakukan pengoptimalan dalam pemungutan pajak, retribusi dan kekayaan daerah dan mampu mengatasi kendala dalam pemerolehan PAD. Adapun rata-rata rasio efisiensi belanja pada Pemerintah Kabupaten Ogan Komering Ulu periode tahun 2013-2017 didapatkan nilai 88,96 yang berarti bahwa efisiensi belanja pada Pemerintah Kabupaten Ogan Komering Ulu dikategorikan Cukup Efisien. 


\section{Pembahasan}

Berdasarkan hasil perhitungan yang telah dilakukan terhadap pendapatan dan belanja daerah pada Pemerintah Kabupaten Ogan Komering Ulu pada tahun 2013-2017 didapatkan hasil bahwa rasio derajat desentralisasi didapatkan nilai 8,22 (sangat kurang) dan dilihat dari Pendapatan Asli Daerah relatif lebih kecil. Kontribusi tersebut dapat dilihat selama 5 (lima) tahun terakhir dari persentase rata-rata yang hanya sebesar $8,06 \%$. Untuk itu, PAD merupakan upaya yang perlu dilakukan oleh Kabupaten Ogan Komering Ulu, belum optimalnya pemungutan retribusi daerah dan pajak daerah menunjukkan bahwa jasa yang dapat dijual masih kurang. Hal ini berarti dalam mengelola daerah, selain berorientasi publik service juga bersifat profit making. Maka dari itu Pemerintah Kabupaten Ogan Komering Ulu harus mengoptimalkan potensi-potensi PAD diantaranya adalah melalui peningkatan pemungutan pajak dan retribusi daerah yang sudah tergali dan sudah terpungut oleh daerah Kabupaten Ogan Komering Ulu.

Hasil rasio ketergantungan keuangan daerah didapatkan nilai 82,75 (Sangat Tinggi). Hal ini dikarenaken masih rendahnya Pendapatan Asli Daerah (PAD) yang mengakibatkan masih besarnya ketergantungan daerah terhadap pemerintah puusat dan propinsi dikarenakan kurang berperannya perusahaan daerah sebagai sumber pendapatan daerah dan dana transfer yang besar tidak sebanding dengan pendapatan asli daerah (PAD). Hal ini menyebabkan masih tingginya ketergantungan daerah kabupaten Ogan Komering Ulu pada Pemerintah Pusat dan propinsi, sehingga kemampuan suatu daerah untuk mengembangkan potensi yang mereka miliki menjadi sangat terbatas. Namun diharapkan pada tahun-tahun berikutnya dana transfer akan semakin mengecil sedangkan pendapatan asli daerah (PAD) tetap pada trend yang meningkat sehingga kedepan, otonomi fiskal daerah Kabupaten Ogan Komering Ulu semakin meningkat. Untuk mengurangi ketergantungan kepada pemerintah pusat, pemerintah Kabupaten OKU dapat melakukan peningkatan PAD baik secara intensifikasi dan ekstensifikasi. Intensifikasi dilakukan dengan cara memperbaiki kinerja pengelolaan dan pemungutan pajak dan retribusi. Ekstensifikasi dapat dilakukan dengan mengidentifikasi potensi daerah yang ada sehingga timbul peluang baru untuk sumber penerimaan daerah yang ada sehinga timbul peluang baru untuk sumber penerimaan daerah. Hal yang bisa dilakukan misalnya dengan membentuk badan usaha atau perusahaan lokal yang mengelola sistem bisnis yang dimungkinkan oleh pemerintah kabupaten dan diandalkan sebagai sumber pendapatan.

Hasil rasio efektivitas Pendapatan Asli Daerah Daerah Kabupaten Ogan Komering Ulu didapatkan sebesar 101,50\% (Sangat Efektif). Hal ini 
disebabkan dalam pengelolaan pendapatan daerah, pemerintah menargetkan pendapatan tidak terlalu besar dengan perkiraan /terealisasi sehingga pemerintah Kabupaten Ogan Komering Ulu dapat mencapai target yang diinginkan. Ini menunjukkan bahwa pemerintah Kabupaten Ogan Komering Ulu telah menganggarkan Pendapatan Asli Daerah dengan cukup baik.

Hasil rasio efisiensi Pendapatan Asli Daerah Daerah Kabupaten Ogan Komering Ulu didapatkan sebesar 61,47\% (Efisien). Hal ini disebabkan dalam pengelolaan pendapatan daerah, pemerintah menargetkan pendapatan tidak terlalu besar dengan perkiraan /terealisasi sehingga pemerintah Kabupaten Ogan Komering Ulu dapat mencapai target yang diinginkan. Ini menunjukkan bahwa pemerintah Kabupaten Ogan Komering Ulu telah menganggarkan Pendapatan Asli Daerah dengan cukup baik.

Hasil rasio efisiensi belanja didapat nilai sebesar 88,96\% (Efisien). Hal ini disebabkan karena biaya yang dikeluarkan oleh Pemerintah Kabupaten Ogan Komering Ulu dalam melakukan pemungutan pajak, retribusi dan kekayaan daerah tepat dan sesuai. Namun kenyataan di lapangan untuk pengoptimalan dalam pemungutan pajak, retribusi dan kekayaan daerah banyak mengalami kendala dimana masih banyak wajib pajak yang tidak mau membayar dan menunggak, selain itu keterbatasan personil juga masih menjadi kendala dalam pemerolehan PAD.

Secara keseluhan dapat disimpulkan bahwa pendapatan daerah berada dalam kategori Efektif sedangkan belanja daerah berada dalam kategori Efisien. Hal ini berarti pendapatan yang diterima Pemerintah Kabupaten Ogan Komering Ulu Periode 2013-2017 cukup baik dan hal tersebut dibarengi dengan belanja daerah yang efektif pula. Hal ini disebabkan karena berpihaknya anggaran pemerintah kepada publik, serta terserapnya seluruh dana yang telah dianggarkan oleh Pemerintah Kabupaten Ogan Komering Ulu.

Pendapatan Asli Daerah (PAD) merupakan salah satu komponen sumber penerimaan daerah selain penerimaan dan transfer, dan lain-lain pendapatan yang sah. Keseluruhannya merupakan sumber pendanaan penyelenggaran pemerintahan di daerah. Dalam upaya penggalian sumber-sumber pendapatan daerah, bukan tanpa masalah. Analisis terhadap objek-objek pendapatan sering tidak berjalan seperti yang diharapkan karena alasan keterbatasan kemampuan sumber daya yang dimiliki dan seringnya rotasi atau mutasi para pejabat-pejabat pemerintah yang berakibat pada banyaknya program-program strategis pemerintah yang tidak berjalan sebagaimana mestinya (Halim, 2014: 169). 
Belanja daerah adalah semua kewajiban daerah yang diakui sebagai pengurang nilai kekayaan bersih dalam periode tahun anggaran yang bersangkutan. (UU No. 33/2004 pasal 1) Belanja daerah dipergunakan dalam rangka mendanai pelaksanaan urusan pemerintahan yang menjadi kewenangan propinsi/kabupaten/kota yang terdiri atas urusan wajib, urusan pilihan, dan urusan yang penanganannya dalam bagian atau bidang tertentu yang dapat dilaksanakan bersama pemerintah pusat dan pemerintah daerah atau antar pemerintah daerah yang ditetapkan dengan ketentuan perundangundangan. Belanja menurut peraturan pemerintah nomor 71 tahun 2010, adalah semua pengeluaran dari rekening kas umum negara/daerah yang mengurangi ekuitas dana lancar dalam periode tahun anggaran yang bersangkutan yang tidak akan diperoleh pembayarannya kembali oleh pemerintah. Definisi lainnya, seperti yang di jelaskan dalam peraturan Menteri dalam Negeri No. 13 Tahun 2006, Belanja adalah kewajiban pemerintah daerah yang diakui sebagai pengurang nilai kekayaan bersih.

Faqihudin (2011) melakukan penelitian tentang "Analisis Kinerja Anggaran Pendapatan dan Belanja Daerah Kota Tegal sebagai Indikator Layanan Publik". Alat analisis menggunakan Analisis Varians Belanja, Analisis Pertumbuhan Belanja, Analisis Pembiayaan, dan Analisis Keserasian Belanja. Hasil penelitian didapatkan bahwa dari kelima analisis yang digunakan dalam mengukur kinerja APBD Kota Tegal yaitu analisis varians belanja, analisis pertumbuhan belanja, analisis efisiensi belanja, analisis pembiayaan kecuali analisis keserasian belanja menunjukkan hasil yang cukup baik sehingga dari sisi analisis ini kinerja APBD Kota Tegal menunjukkan hasil yang positif.

Gozaliem (2013) melakukan penelitian tentang "Analisis Pendapatan Dan Belanja Pada Pemerintah Kota Bitung tahun anggaran 2010-2012. Alat analisis menggunakan rasio derajat desentralisasi ,rasio ketergantungan keuangan daerah, rasio efektifitas pada, analisis varians belanja, rasio efisiensi belanja. Hasil penelitiannya menunjukkan bahwa pendapatan belum dapat terlaksana dengan baik karena realisasi meningkat setiap tahun melebihi yang dianggarkan.

Sudarwanto (2013) melakukan penelitian tentang "Analisis Anggaran Pendapatan Belanja Daerah Pada Propinsi DKI Jakarta Tahun Anggaran 2009-2012" Alat analisis yang dugunakan adalah rasio pajak, rasio pajak perkapita. Dari hasil penelitian menunjukkan bahwa anggaran Pendapatan Belanja Daerah dengan realisasinya pada Propinsi DKI Jakarta tahun anggaran 2009-2011,Kinerja pendapatan pemerintah DKI Jakarta dilihat dari analisis Varians, secara umum dapat dikatakan sudah baik. 


\section{KESIMPULAN DAN SARAN \\ Kesimpulan}

Dari hasil analisis terhadap pendapatan dan belanja daerah pada Pemerintah Daerah Kabupaten Ogan Komering Ulu Periode 2013-2017 didapatkan hasil:

1.Rasio derajat desentralisasi Sangat Kurang, rasio ketergantungan keuangan daerah Sangat Tinggi, efektivitas Pendapatan Asli Daerah Sangat Efektif, rasio efisiensi Pendapatan Asli Daerah efisien dan rasio efisiensi belanja Cukup Efisien.

2. Analisis terhadap pendapatan daerah pada Pemerintah Daerah Kabupaten Ogan Komering Ulu Periode 2013-2017 sangat efektif dan efisien, sedangkan belanja daerah cukup efisien.

\section{Saran}

1. Kepada Pemerintah Kabupaten Ogan Komering Ulu agar dapat mengurangi tingkat ketergantungan kepada pemerintah pusat yaitu dengan mengoptimalkan potensi-potensi sumber daya yang ada khususnya peningkatan Pendapatan Asli Daerah (PAD) atau dengan meminta kewenangan yang lebih luas untuk mengelola sumber pendapatan lain yang masih dikuasai oleh pemerintah pusat/provinsi.

2. Bagi peneliti selanjutnya agar meneliti kembali mengenai analisis pendapatan dan belanja daerah dengan menggunakan rasio kinerja keuangan daerah yang berbeda dan objek yang berbeda pula.

\section{DAFTAR PUSTAKA}

Adisasmita, Rahardjo, 2011, Pembiayaan Pembangunan Daerah, Graha Ilmu: Yogyakarta.

Bastian, Indra, 2011, Akuntansi Sektor Publik : Suatu Pengantar, Erlangga: Jakarta.

Bisma dan Susanto, 2010, Evaluasi Kinerja Keuangan Pemerintah Provinsi Nusa Tenggara Barat. Jurnal Ilmiah Ekonomika Vol 4 No 3 , 75-86 Desember, Jakarta.

Darise, Nurlan, 2012, Akuntansi Keuangan Daerah (Akuntansi Sektor Publik), Indeks: Jakarta. 
Faqihudin, 2011, Analisis Kinerja Anggaran Pendapatan dan Belanja Daerah Kota Tegal sebagai Indikator Layanan Publik. Jurnal Universitas Pancasakti Tegal, Jakarta.

Gozaliem, Angel, Juliet, 2013. Analisis Pendapatan Dan Belanja pada Pemerintah Kota Bitung Jurnal EMBA. Vol 1 No 4, 2004-2013 Desember. Jakarta.

Halim, Abdul, 2014, Akuntansi Sektor Publik : Akuntansi Keuangan Daerah, Salemba Empat: Jakarta.

Halim, 2014, Bunga RampaiMmanajemen Keuangan Daerah: Pengelolaan Keuangan Daerah, UPP STIM YKPN: Yogyakarta.

Handayani dan Yuwono, 2017, Analisis Kinerja Keuangan Daerah, BPFE: Yogyakarta.

Mahmudi, 2011, Analisis Laporan Keuangan Pemerintah Daerah, UPP STIM YKPN : Yogyakarta

Mardiasmo, 2014, Akuntansi dan Keuangan Sektor Publik, Andi: Yogyakarta.

Mahsun dkk, 2011, Akuntansi Sektor Publik, BPFE: Yogyakarta.

Permendagri, 2006, Pedoman Pengelolaan Keungan Daerah. Jakarta.

Siahaan, P. Marihot, 2013, Pajak Daerah dan Retribusi Daerah. PT Rajagrafindo Persada: Jakarta.

Sudarwanto, adenk, 2013, Analisis APBD Tahun 2012. Jurnal STIE Semarang. Vol 5 No 1, 1-14, Februari. Semarang. 